2. Om nasjonale kvalitetsindikatorer. Helsedirektoratet. https://helsedirektoratet.no/statistikk-og-analyse/kvalitetsindikatorer/ om-nasjonale-kvalitetsindikatorer (20.7.2015)

\section{Re: Hvordan sammenlikner vi kvalitet i helsetjenesten?}

Asplin \& Fagermoen skriver reflektert om problemene med kvalitetsmåling i helsetjenesten (1). Formen er mild, men konklusjonen drepende: Er rangeringen av sykehus på helsenorge.no troverdig? Svarene fra helsebyråkratiet er dessverre forutsigbart «god-dagmann-økseskaft»: Doris Tove Kristoffersen og medforfattere skriver om statistiske metoder som ikke kan fange opp de systematiske feilene Asplin \& Fagermoen påpeker. Og Cecilie Daae og medarbeidere skriver om Helsedirektoratets luftige visjoner.

Sakens kjerne er denne:

- Helsedirektoratet og Kunnskapssenteret går langt $\mathrm{i}$ å innrømme at dagens system er uegnet til å rangere sykehus, bl.a. pga. utilstrekkelig risikojustering og justering for sykehusenes ulike roller.

- Likevel publiseres resultatene på helsenorge.no på en måte som inviterer pasienter til å tro de kan få vite hvor de får best behandling og pressen til å publisere pikante rangeringer.

- En halv milliard kroner av helsebudsjettet skal fordeles ut fra disse rangeringene (2), til tross for at deres grad av presisjon altså ikke gjør dem egnet for det.

- Rangeringer påvirker kodepraksis - sterkere dess sterkere incentiver de er koblet til. Det kan ikke justeres vekk statistisk. Sørg for å kode alle pasienter med lett forhøyede troponinverdier som «hjerteinfarkt», alle med kraftig bronkitt som «pneumoni» og alle med uspesifikke nevroradiologiske funn som «hjerneslag», og du får i pose og sekk: Høy DRG-refusjon og høy kvalitetsskår. Slike betraktninger er blitt hverdagen i de kliniske miljøene. Det trekker helsepersonellets oppmerksomhet vekk fra det som faktisk betyr noe for behandlingskvaliteten.

- Kvalitetsindikatorene kan påvirke behandlingspraksis på måter som kan være uønsket. Dels ved at sykehusene forsøker å unngå pasienter med høy risiko, og dels ved at metoder som «teller» anvendes også der annen behandling hadde vært best (3).

- Kvalitetsindikatorene gir mye arbeid for sykehusenes og helseforetakenes omdømmebyggere (informasjonskonsulenter), for å fremheve de gode tallene og bortforklare de dårlige. Informasjonsstabene vokser, og de kliniske miljøene må bruke mer av sin tid på å gi dem data. Dette systemet får ikke helsetjenesten til å gi god behandling, men får det til å se ut som behandlingen er god.

Det er derfor høy risiko for at arbeidet med kvalitetsindikatorer gjennom indirekte effekter som er åpenbare sett fra grunnplanet, men dårlig forstått i byråkratiet - fører til kvalitetsforringelse snarere enn forbedring.

Selvsagt skal alle som gir helsetjenester evaluere kvaliteten, men evalueringen må være relevant i den konteksten behandlingen gis. Slik egenevaluering har gode tradisjoner i helsetjenesten, men synes nå å avta, trolig fordi man i stedet strever for å rapportere «pene» tall tjenestevei. Det er ikke kjent hva ovenfra-og-ned-arbeidet med kvalitetsindikatorer koster, men bare de direkte utgiftene må være på mange millioner. Disse pengene ville vært bedre anvendt til reell kvalitetsforbedring der helsetjenestene faktisk gis.

\section{Torgeir Bruun Wyller}

t.b.wyller@medisin.uio.no

Torgeir Bruun Wyller (f. 1960) er professor ved Geriatrisk avdeling, Oslo universitetssykehus og leder av Helsetjenesteaksjonen.

Ingen oppgitte interessekonflikter.

\section{Litteratur}

1. Asplin M, Fagermoen E. Hvordan sammenlikner vi kvalitet i helsetjenesten? Tidsskr Nor Legeforen 2015; 135: 1112-3

2. Meld. St. 10 (2012-2013). God kvalitet - trygge tjenester - Kvalitet og pasientsikkerhet i helse- og omsorgstjenesten. www.regjeringen.no/nb/dokumenter/ meld-st-10-20122013/id709025/ (29.7.2015).
3. Frøyshov HM. Hva er god behandling ved akutt hjerneslag? Tidsskr Nor Legeforen 2015; 135: 625

\section{Re: Hvordan sammenlikner vi kvalitet i helsetjenesten?}

Debattinnlegget til Asplin \& Fagermoen (1) har ført til gode kommentarer og ytterligere påpeking av begrensningene for noen av de 79 kvalitetsindikatorene som per mai 2015 publiseres på helsenorge.no. Daae og medarbeidere minner om at det er mange brukere og flere aspekter som skal belyses av et nasjonalt indikatorsystem.

Wyller skriver bl.a. at «...Kunnskapssenteret går langt i å innrømme at dagens system er uegnet til å rangere sykehus». Dette krever en kommentar: Når vi sorterer usikre tall, vil rangeringen, dvs. rekkefølgen, bli usikker. Dette skyldes den statistiske variabiliteten i tallene, som det er vanskelig å gjøre noe med. Selv med perfekt datakvalitet og perfekt justering for forskjeller i pasientsammensetning, vil vi ikke kunne gi en sikker rangering. Dette er grunnen til at vi advarer mot tolkning av rekkefølgen i tabellen over indikatorer (2). Ved bruk av statistiske metoder våger vi imidlertid å påstå at noen sykehus gjør det bedre eller dårligere enn gjennomsnittet. Forslaget fra Asplin \& Fagermoen om å presentere konfidensintervall, kan bidra til å illustrere den statistiske usikkerheten som er i overlevelsessannsynlighetene.

Kunnskapssenteret mener at det er nyttig å ha et nasjonalt kvalitetsindikatorsystem. Internasjonalt anerkjennes bruken av indikatorer (3), og mange land har utviklet indikatorsystemer. Hvis et sykehus kommer signifikant dårligere ut enn andre sykehus, bør sykehuset gå gjennom egne data og praksis. Dette kan gi innsikt i om sykehuset gir suboptimal behandling eller har avvikende kodepraksis. Blant tre norske sykehus som kom signifikant dårligere ut da 30-dagersoverlevelse ble publisert i 2011, førte gjennomgang av datagrunnlaget til at sykehusene fikk bedre forståelse av egne data og kvalitetsforbedringstiltak ble satt i gang eller videreført (4).

Overlevelse og reinnleggelse er basert på pasientadministrative data som er relativt billige og lett tilgjengelige. Slik registrering for å dokumentere pasientbehandlingen har foregått i mange år, og har vært brukt til innsatsstyrt finansiering. Vi tror at alle tilstreber riktigst mulig kodebruk. Ettersom mengden av kvalitetsregistre i Norge er økende, vil vi etter hvert kunne utnytte data fra begge kilder.

\section{Doris Tove Kristoffersen}

dok@nokc.no

Doris Tove Kristoffersen (f. 1962) er statistiker og forsker ved Nasjonalt kunnskapssenter for helsetjenesten.

Ingen oppgitte interessekonflikter.

Litteratur

. Asplin M, Fagermoen E. Hvordan sammenlikner vi kvalitet i helsetjenesten? Tidsskr Nor Legeforen 2015: 135: 1112-3.

2. Lindman AS, Hassani S, Kristoffersen DT et al. 30-dagers overlevelse og reinnleggelse ved norske sykehus for 2013. Notat 2014. Oslo: Kunnskapssenteret, 2014.

3. Schold JD, Nicholas LH. Considering potential benefits and consequences of hospital report cards: what are the next steps? Health Serv Res 2015; 50: 321 -9. Kristoffersen DT, Helgeland J, Waage HP et al. Survival curves to support quality improvement in hospitals with excess 30-day mortality after acute myocardial infarction, cerebral stroke and hip fracture: a before-after study. BMJ Open 2015; 5: e006741.

\section{Re: E-sigaretter - til skade eller nytte?}

Jeg ønsker å komme med noen kommentarer til Sanner \& Grimsruds svar:

Sanner \& Grimsruds svar på min kritikk leser jeg kun som en gjentakelse av det som står i kronikken (1). Jeg er klar over at de er redde for at en etablert nikotinavhengighet vil gjøre det lettere 